\title{
Promoting Learners' Skill in Composing Poetry Using Contextual Teaching and Learning (CTL) Approach
}

\author{
Emon Candra \\ Institut Agama Islam Negeri Bengkulu \\ emoncandra01@gmail.com \\ Khermarinah \\ Institut Agama Islam Negeri Bengkulu \\ khermarina@gmail.com \\ Randi \\ Institut Agama Islam Negeri Bengkulu \\ randijufry@gmail.com
}

\begin{abstract}
This research was aimed to promote the quality of learners' skills in composing poetry through the implementation of contextual teaching and learning approach towards the second grade students of SMP Negeri 05 Bengkulu City. It was designed by implementing a qualitative approach. The object of this research was the learners' skills in writing poetry. In this research, the researchers used observation, interview, and documentation as the data collection technique and triangulation as the data validity technique. The data validity technique included triangulation of source, technique, and time. The data analysis technique consisted of several steps: 1) Data Reduction, 2) Data Display, 3) Withdrawal Conclusion and Verification, 4) Final Conclusion. The result of this research revealed that the implementation of a contextual teaching and learning approach was able in promoting the learners' skills in writing poetry. It could be understandable as this approach enabled the learners to compose poetry effortlessly.
\end{abstract}

Keywords: CTL Approach, Poetry Writing Skill

\section{A. Introduction}

In the world of education in Indonesia, there are several skills taught to the students. One of them is literacy skills (reading or writing) that absolutely should have been taught to the students. Thus, by mastering this kind of skill, students are able to enhance their competence. It can be deemed that education can be used as the process or medium to develop students' characters and moral values for the students.

Education can be recognized as one of factors that can influence and has a role in social life. It relates to a process which enables students to have an adaptation to their society (Oemar Hamalik, 2001). Therefore, it can create a better civilization and one's social status. In the process of education, 
teaching and learning become the major activities. The success of education can be identified from the process of teaching and learning itself.

Indonesian language has become one of compulsory lessons in education. In this case, there are several language skills that should be mastered by the students including listening, speaking, reading, and writing skills (Henry Guntur Tarigan, 2015). The skills have the same crucial roles as it enables students to comprehend the learning materials effortlessly.

Ideas can be expressed directly or indirectly. Expressing ideas indirectly can be done through writing. Writing can be defined as a process of expressing ideas, feeling, and experience in the form of written communication. It relates to the ability of comprehension and reasoning. One of the literary works that can be made by students is to write poetry. In this case, the students are required to be able to express expression, emotion, thought or imagination and to obey the writing rules.

The ability to write poetry should be mastered by students. It has many advantages for the students if it is conducted continuously. There are many great poets who are able to be their inspiration in developing their ideas, for instance, Chairil Anwar's poems entitled "Aku", "Cintaku Jauh di Pulau", and "Doa". Poetry writing learning taught in schools is expected to have good impacts or roles for the development of students' literacy skills. Through the learning lesson, students are given the opportunity to express thoughts or feelings in writing, and be able to create feelings of interest in a literary work. Thus, it is certainly able to improve students' observation, imagination, creativity and language skills.

Nevertheless, in the Indonesian learning process, especially at the second grade students of SMP Negeri 05 Bengkulu city, the students still have poor understanding and ability in writing poetry. This case is caused by many factors, such as the students' learning interest and the learning effectiveness by the teachers including the learning method and learning approach. Moreover, it is also caused by the aspects of supporting facilities in the learning process. 
Furthermore, literature learning in the classroom still tends to cause students to feel bored in the learning process. It is also caused by the lack of learning motivation and interest in learning to write poetry. Moreover, there are still many students who have difficulties expressing their ideas or feelings in the form of poetry.

Based on the learning problems faced by the students in learning and producing poetry, the researchers were interested to overcome the problems by implementing CTL approach at the second grade students of SMPN 05 Bengkulu City. By implementing this learning approach in learning to write poetry, it was expected to be able to enhance the quality of students' learning outcomes in writing poetry. This learning approach can be categorized as a learning approach that links the material studied with the students' real life, such as in the family, school, and society (Kokom Komalasari, 2010).

The contextual approach is considered as an effective approach that is able to improve the learning outcome in writing poetry. The implementation of this approach enables the students to participate in the learning process. This approach was chosen for several reasons. The reasons include that this approach is considered as a student-centered approach as the students are allowed to express their ideas, points of views, and opinions actively, and to solve certain learning problems in writing using their imagination and creativity. In this case, the teachers are as the learning facilitators. Thus, this approach is intended to be able to develop the students' critical thinking skills, creativity, and imagination development in accordance with their learning interest in writing poetry.

In the context of the aforementioned cases, the researchers were interested in conducting the research entitled 'Promoting Learners' Skill in Writing Poetry Using Contextual Teaching and Learning (CTL) Approach towards the Second Grade Students of SMP Negeri 05 Bengkulu City" as the students still had poor ability in writing a poetry. 


\section{B. Research Method}

This research was designed by implementing a qualitative approach. Qualitative research is a research method used to examine the condition of natural objects (as opposed to experiments). The research results tend to emphasize the meaning. Instead of generalization (Sugiyono, 2018). In this research, the researchers were the key instruments. The data collection was done through triangulation by implementing observation, interviews, documentation as the data collection techniques. Moreover, the data were analyzed inductively.

Furthermore, qualitative research is used to contribute to theory, practice, policy, social issues and action (Djam'an Satori and Aan Komariah, 2013). The subjects of this study were the second grade students of SMP Negeri 05 Bengkulu City consisting of 12 students from class A to E and the teachers of SMP Negeri 05 Bengkulu City consisting of two Indonesian teachers of the second grade, namely Mrs. Zaleka and Mrs. Linda Hismimurti. The object of this research was the students' poetry writing skill, so the expected aim of this research was to improve the students' writing skill and learning outcomes in writing poetry by emphasizing the learning process.

In this research, the researchers implemented triangulation as the data validity technique. The data validity technique included triangulation of source, technique, and time. The data analysis technique consisted of several steps: 1) Data Reduction, 2) Data Display, 3) Withdrawal Conclusion and Verification, 4) Final Conclusion.

\section{Result and Discussion}

\section{Result}

This qualitative research was conducted at the second grade students of SMP Negeri 05 Bengkulu City by involving two Indonesian language teachers and several eighth grade students. The informants of this research were Mrs. Zuleka and Mrs. Linda Hismimurti and the second grade students. 
Based on the research problems and limitation stated in the previous explanations, the researchers described the results of this research, as follows:

a. The Implementation of Contextual Teaching and Learning Approach in Promoting the Students' Skill in Writing Poetry

To find out how the implementation of contextual teaching and learning approach carried out by Indonesian language teachers in learning to write poetry at the second grade students of SMP Negeri 05 Bengkulu City, the researchers conducted interviews with several informants and respondents. After obtaining data from the interviews, the researchers made observations towards the research problems directly to the school. In more detailed explanation, the researchers gave the explanations, as follows:

1) By explaining the contextual teaching and learning approach and poetry

In the process of teaching learning in schools, a teacher, especially an Indonesian teacher, usually will explain the essence of the contextual teaching and learning approach used in learning to write poetry. This is what researchers found in Indonesian language teachers at SMP Negeri 05 Bengkulu City. In this case, the teacher can directly ask what a contextual teaching and learning approach is, but the students will be confused if they do not get any previous explanation by the teacher towards the material.

Furthermore, one of the Indonesian language teachers said that every teacher had their own way in delivering a lesson, but she claimed that she was used to explaining the learning material first before asking questions to her students. In this case, she assumed that the students would be confused if the students were not given the explanation first in the learning process. In addition, the other Indonesian teacher, Mrs. Linda Hismimurti said that each student had different abilities, especially if the material to be delivered used a foreign language, so the teacher should explain the learning material first. 
Apart from the interview results above, based on the results of observations, the researchers also revealed that the Indonesian language teachers would explain the learning material first before discussing examples or giving assignments to the students. Therefore, based on the findings of these interviews and observations, it could be concluded that one of the ways teachers applied the contextual teaching and learning approach in learning to write poetry at the second grade students of SMP Negeri 05 Bengkulu city was to explain the essence of the contextual teaching and learning approach itself to the students.

2) By providing the related examples directly to the students

A teacher must be able to master learning materials and to provide examples of learning materials to the students directly. Therefore, it is what was found in the implementation of contextual teaching and learning approach towards the process of learning to write poetry at the second grade students of SMP Negeri 05 Bengkulu City. As expressed by Mrs. Zaleka who said that in applying the contextual teaching and learning approach in learning to write poetry, direct examples should be given by teachers to the students. in line with the statements above, Mrs. Linda Hismimurti argued that giving examples directly to students and students was absolutely invited to see the direct object in making poetry, for instance, when a poetry was entitled "A Flower", the students needed to be invited to a garden or school yard where there were flowers so that they could see the object directly where it could be easier for the students to compose poetry.

3) By linking students' real life with the themes that would be used in writing poetry

In the implementation of the CTL approach, the teacher usually can relate learning materials to the students' real life, student experiences and others. This is also what the researchers found in learning to write poetry in the second grade students of SMP Negeri 05 Bengkulu city. As expressed by Mrs. Zaleka, who said:that in applying the contextual 
approach (CTL) in learning to write poetry, the teacher would first explain the material about poetry and the essence of contextual approach. Moreover, after students understand what poetry and what contextual approaches were, the teacher determined the theme of the poetry that would be made by students. In this case, they needed to carry out the implementation of making poetry outside the classroom in accordance with the predetermined theme, so students could see the object directly in creating a beautiful poetry.

In addition, in line with the lines above, Mrs. Linda Hismimurti argued that the implementation of a contextual approach in learning to write poetry had been done by linking learning to write poetry with students' real life. After the poetry material was explained, the students would find it easier to compose poetry because poetry was made by being related to reality or the students themselves. The way to make it should be based on what students saw, felt, or had experienced.

Apart from the results of the interviews above, based on the results of observations, the researchers also revealed that the teachers linked learning to write poetry with students' reality or real life. Therefore, based on the findings of these interviews and observations, it can be concluded that the implementation of the CTL approach in promoting the students' skill in composing poetry at the second grade students of SMP Negeri 05 Bengkulu City was done by linking or connecting the learning material to compose poetry with students' real life and student experiences. so that students were able to find it easier in composing words in the form of poetry.

4) Promoting the students' skill in composing poetry through contextual approach

In promoting the students' skill in composing poetry using CTL approach. The teacher should do several stages. In this case, Mrs. Zaleka claimed that to develop the ability to write poetry using the CTL approach requires several stages. It started from giving explanations and 
examples in writing poetry, linking or connecting learning materials with the themes that would be made to compose poetry and doing poetry writing exercises continuously so that the ability to write poetry could be promoted.

5) Supporting and inhibiting factors in the implementation of the contextual approach in learning to compose poetry

Based on the results of the research that the researchers had done int SMP Negeri 5 Bengkulu city, it could be seen that there were several supporting and inhibiting factors in the implementation of contextual approach in learning to compose poetry. As expressed by Mrs. Zaleka who said that the first supporting factor in implementing the contextual teaching and learning approach was the use of teaching aids to write poetry, for instance by giving examples with paintings, flowers, and so forth. The second supporting factor was the teacher's skill in applying the contextual approach, while the negative factors were the lack of insight into poetry, the students' poor ability and the students' low learning motivation, enthusiasm, interest in composing poetry, and the students' unsupported environment.

Furthermore, Mrs. Linda Hismimurti said that the supporting factor in implementing the contextual teaching and learning approach in learning to write poetry could be the teacher's ability to develop learning to write poetry by linking learning materials with students' real life so that students could find it easier to understand the learning material, while the inhibiting factor was that there were still students who did not have interest in writing poetry.

\section{b. The effectiveness of contextual teaching and learning approach in} promoting the students' skill in composing poetry

To find out the effectiveness of contextual teaching and learning approach in promoting the students' skill in composing poetry at the second grade students of SMP Negeri 05 Bengkulu city, the researchers conducted interviews to several informants and respondents. The 
implementation of the CTL approach was able to develop the students' skill in composing poetry. Mrs. Zaleka, and Mrs. Linda argued that this approach was very effective to promote the students' skill in composing poetry since it enabled the students to create poetry easily.

In addition, several students of class VIII at SMP Negeri 05 Bengkulu city, Rellissya Putri Maharani expressed that the implementation of the contextual approach used by the teacher in learning to write poetry was able to help her to develop her skill in composing poetry as the approach help the student to understand the material related to poetry, to compose poetry, and to develop new ideas effortlessly.

Nevertheless, Arsyad Hadi Nugroho argued that the contextual approach used by the teachers in learning to write poetry was not really effective in promoting his skill in understanding the material and in learning to write poetry. He claimed that he was still not interested in learning to write poetry and found it difficult to write poetry.

1) The students' poetry writing outcomes after using a contextual approach

The results of writing poetry after using the CTL approach can be different for each student. This is what the researchers found among the second grade students of SMP Negeri 05 Bengkulu City. Mrs. Zaleka, said that the results of writing poetry using CTL was better as it directly related the learning material to the students' real life. In this case, the students found it easier to understand how to compose poetry.

Furthermore, Mrs. Linda Hismimurti reported that the results of each student's poetry writing were absolutely different depending on their talents and interests because each student did not have the same ability to compose poetry. However, when it was viewed generally, the students' poetry writing results were better after using the CTL approach.

2) Students' interest and response in learning to write poetry 
Each student certainly has their own interest in learning and of course has a different response in receiving a lesson. This is what the researchers found among the second grade students of SMP Negeri 05 Bengkulu City. Mrs. Zaleka commented that the students' interest and response were good and students felt happy because the learning material was linked to their real life. Nevertheless, this is different from what was expressed by one of the Indonesian language teachers, Mrs. Linda, who said that the students' interest in the class depended on the students and their responses towards the learning material were different.

3) The advantages and disadvantages of using a contextual approach

From the results of interviews with the Indonesian language teachers, it could be seen that the advantage of using a contextual approach included that the students were more productive in composing poetry and the learning process became more meaningful. It could be reasonable as the students were able to express their own feelings into poetry. However, the disadvantages of this approach included that the students had the lack of willingness and experience in choosing words. Thus, the implementation of learning to write poetry using a contextual approach was still not understood well and the students still found it difficult to choose appropriate dictions for their poetry as they had low interest in learning to write poetry.

\section{Discussion}

Teaching and learning activities position students as subjects and objects of teaching activities. Therefore, the core of the teaching process is the learning activities of students in achieving a teaching goal (Syaiful Bahri Djamarah, 2010). Learning is essentially a "change" that occurs within a person after the end of learning activities (Nana Sudjana, 1991). The CTL approach is a learning concept that helps teachers relate the material they teach to students' real-world situations and encourages the knowledge they have and its application in their lives as family and community members (Riyanto and Yatim, 2009). In line with the lines above, according to Sanjaya 
CTL is a learning approach that emphasizes the process of full student involvement to be able to find the material being studied and relate it to real life situations so as to encourage students to be able to apply it in their life (Wina Sanjaya, 2007).

By using the CTL approach, learning becomes more meaningful and real (Hosnan, 2002). In this case, the CTL approach is applied to learning to write poetry. Poetry includes smaller units, such as rhymes, rhymes, and ballads (Dendy Sugono, 2011). Poetry is a recording and interpretation of important human experiences, composed in the most memorable form (Rahmat Djoko Pradopo, 2010). Based on the presentation of the results of the research, the discussion in this research is presented, as follows:

\section{a. The Implementation of Contextual Teaching and Learning Approach in Promoting the Students' Skill in Writing Poetry}

1) By explaining the contextual teaching and learning approach and poetry

The contextual approach (Contextual Teaching and Learning (CTL) is a learning concept that helps teachers relate the material they teach to students' real-world situations and encourages the relationship between their knowledge and its application in their lives as family and community members. Indonesian language teachers apply the CTL approach. will explain first about the learning material before asking questions to students as they will be confused if it is not explained first.This is what the researchers found at the second grade students of SMP Negeri 05 Bengkulu city.

2) By providing the related examples directly to the students

A teacher must master learning and be able to provide examples of learning materials. Therefore, it is a must for a teacher to give examples directly to students. This is what Indonesian language teachers did in applying a contextual teaching and learning approach in learning to write poetry to the second grade students of SMP Negeri 05 Bengkulu City. 
3) By linking students' real life with the themes that would be used in writing poetry

The main objective of CTL is to help students to relate the meaning of their academic learning lessons. When students find meaning in their lessons, they will learn and remember what they learned. CTI enables students to relate the content of academic subjects to the context of their daily life to find meaning (Elaine B. Johnson, 2009). From the results of interviews and observations of this research, it could be seen that in applying the CTL approach, the teacher would relate learning materials to students' real life, experiences and so forth. It could be related to what students saw, felt, and experienced. This is also what the researchers found in learning to write poetry at the second grade students of SMP Negeri 05 Bengkulu City.

4) Promoting the students' skill in composing poetry through contextual approach

In promoting students' skill in composing poetry using the CTL approach, teachers can conduct this approach through several procedures. It can be started from giving an explanation, examples of poetries, connecting or relating the learning material to themes which will be used in composing poetry, and making exercise for the students continuously so that the students' skill can be promoted increasingly.

5) Several steps in implementing CTL approach in promoting students' skill in writing poetry

There are several steps in implementing the CTL approach in the learning and teaching process. In this case, one of Indonesian language teacher argued that the steps included that by giving a brief explanation, information, or explication towards the essence of CTL approach to the students before continuing to promote the students' ideas to conduct meaningful learning process independently, asking questions to develop the students' curiosity in learning poetry, and providing some related 
examples by inviting the students to compose poetry related to the real life by looking at the object directly.

\section{b. The effectiveness of contextual teaching and learning approach in promoting the students' skill in composing poetry}

From the findings of the research through the process of observation and interviews by the researchers to the respondents, it could be revealed that the implementation of the contextual teaching and learning approach was able to promote the students' skills in writing poetry.

1) The Implementation of CTL approach is very effective to promote the students' skill in writing poetry

The CTL approach enabled the students to compose poetry more easily to compose poetry, develop poetry writing skills as in the learning process, the teachers have explained the important points of the learning material related to the contextual approach and poetry. Thus, it could be easier for the students to understand the learning material easily and to express their ideas in the form of poetry.

2) The students' poetry writing outcomes after using a contextual approach

The results of writing poetry after using the CTL approach are different for each student. This is what the researchers found among the second grade students of SMP Negeri 05 Bengkulu City. The results of writing poetry for each student depending on their talents and interests because each student did not have the same ability to compose poetry. However, when it was viewed generally, the students' poetry writing results were better after using the CTL approach.

3) Students' interest and response in learning to write poetry

Students' interest and response in learning to write poetry were different for each student. They certainly had their own interest in learning and had different responses in understanding the learning lesson. The interest of students in the class depended on the students themselves and the students' responses which were not the same.

4) The advantages and disadvantages of CTL approach 
Seen from the result of this research, the researchers found that there were some advantages of this approach in learning poetry. For instance, this approach was able to make the learning process more interesting, meaningful, authentic and productive. It could be understandable as the students were able to express their feelings and ideas through poetry. Moreover, the students could relate the relationship of their learning experiences to their real life. Meanwhile, the disadvantage of this approach came from the internal problem of the students themselve. For instance, some students had low interest and lack of learning experiences in choosing appropriate words (diction).

\section{Conclusion}

Based on the previous explanations and discussion of the result of this research, it can be concluded that the implementation of the contextual teaching and learning approach in promoting the students' skill in writing poetry at the second grade students of SMP negeri 05 Bengkulu City was conducted by providing an explanation of the contextual teaching and learning approach and poetry, providing direct examples, linking the material to the real life, and providing stages or steps in the learning. Thus, the implementation of the contextual teaching and learning (CTL) approach could be proven effective in promoting the students' skill in writing poetry as this approach enabled the learners to write poetry effortlessly.

\section{References}

Djamarah, S.B., \& Aswan, Z. (2010). Strategi Belajar Mengajar. Jakarta: Rineka Cipta.

Hamalik, O. (2001). Proses Belajar Mengajar. Jakarta: Bumi Aksara.

Hosnan. (2014). Pendekatan Saintifik dan Kontekstual dalam Pembelajaran Abad 21. Bogor: Ghalia Indonesia.

Johnson, E. B. (2014). Contextual Teaching and Learning: Menjadikan Kegiatan Belajar Mengajar Mengasyikan dan Bermakna. Bandung: Kaifa. 
Komalasari, K. (2010). Pembelajaran Kontekstual. Bandung.

Pradopo, R.D. (2014). Pengkajian Puisi. Yogyakarta: Gadjah Mada University Press.

Riyanto, Y. (2009). Paradigma Baru Pembelajaran: Sebagai Referensi Bagi Guru/Pendidik Dalam Implementasi Pembelajaran Yang Efektif dan Berkualitas. Jakarta: Kencana.

Rusman. (2012). Model-Model Pembelajaran. Depok: Raja Grafindo Persada.

Sanjaya, W. (2007). Strategi Pembelajaran Berorientasi Standar. Jakarta: Kencana Prenada Media Group.

Satori, D. dan Aan, K. (2013). Metodelogi Penelitian Kualitatif. Bandung: Alfabeta.

Sudjana, N. (1991). Dasar-Dasar Proses Belajar Mengajar. Bandung: Sinar Baru Algensindo.

Sugiyono. (2018). Metode Penelitian Kualitatif (Untuk Penelitian yang bersifat: eksploratif, enterpretif, interaktif, dan konstruktif). Bandung: IKAPI.

Sugono, D. (2011). Buku Praktis Bahasa Indonesia Jilid 1. Jakarta.

Tarigan, H.G. (1994). Menulis Sebagai Salah Satu Keterampilan Dalam Berbahasa. Bandung: Angkasa.

Wiranta, V. S. (2020). Metodelogi Penelitian Lengkap, Praktis, dan Mudah Dipahami. Yogyakarta: Pustaka Baru Press. 